\title{
Impact of agronomic uncertainty in biomass production and endogenous commodity prices on cellulosic biofuel feedstock composition
}

\author{
Jerome Dumortier
}

February 18, 2015

\begin{abstract}
This paper evaluates the effect of agronomic uncertainty on bioenergy crop production as well as endogenous commodity and biomass prices on the feedstock composition of cellulosic biofuels under a binding mandate in the United States. The county-level simulation model focuses on both field crops (corn, soybean, and wheat) and biomass feedstocks (corn stover, wheat straw, switchgrass, and miscanthus). In addition, pasture serves as a potential area for bioenergy crop production. The economic model is calibrated to 2022 in terms of yield, crop demand, and baseline prices and allocates land optimally among the alternative crops given the binding cellulosic biofuel mandate. The simulation scenarios differ in terms of bioenergy crop type (switchgrass and miscanthus) and yield, biomass production inputs, and pasture availability. The cellulosic biofuel mandates range from 15 to 60 billion liters. The results indicate that the 15 and 30 billion liter mandates in the high production input scenarios for switchgrass and miscanthus are covered entirely by agricultural residues. With the exception of the low production input for miscanthus scenario, the share of agricultural residues is always over $50 \%$ for all other scenarios including the 60 billion liter mandate. The largest proportion of agricultural land dedicated to either switchgrass or miscanthus is found in the Southern Plains and the Southeast. Almost no bioenergy crops are grown in the Midwest across all scenarios. Changes in the prices for the three commodities are negligible for cellulosic ethanol mandates because most of the mandate is met with agricultural residues. The lessons learned are that (1) the share of agricultural residue in the feedstock mix is higher than previously estimated and (2) for a given mandate, the feedstock composition is relatively stable with the exception of one scenario.
\end{abstract}

\section{Introduction}

Rising concern about energy security and greenhouse gas emissions has led to the development of biofuel and biomass production in the United States. In 2011, U.S. corn ethanol production used 127 million metric tons of grain, which represents almost $40 \%$ of corn production (FAPRI, 2012). Corn ethanol competes with food, feed, and export use of corn and could potentially cause land-use change globally (Searchinger et al., 2008; Fargione et al., 2008). Those effects are difficult to measure in reality and estimates are highly dependent on the underlying assumptions (Hertel et al., 2010; Dumortier et al., 2011; Swinton et al., 2011). In addition, roughly one-third of corn used for ethanol is returned as feed in the form of dried distillers grains with solubles (DDGS). Advanced (or cellulosic) biofuels can circumvent the problem of indirect land-use change

This is the author's manuscript of the article published in final edited form as:

Dumortier, J. (2015). Impact of agronomic uncertainty in biomass production and endogenous commodity prices on cellulosic biofuel feedstock composition. GCB Bioenergy. http://dx.doi.org/10.1111/gcbb.12238 
and competition with other grain uses because it uses agricultural and forest residues as feedstock (Carriquiry et al., 2011; Babcock et al., 2011). As an alternative to transportation fuel production, cellulosic feedstock can also be used for co-firing in power plants because of its suitability to serve as a substitute for coal (Khanna et al., 2011b; Brechbill et al., 2011; Dumortier, 2013a). Given the availability of biomass resources and the potential use for transportation fuel and electricity production, questions concerning the effects of cellulosic feedstock production arise. The purpose of this paper is to analyze the feedstock mix of cellulosic ethanol production, land allocation at the county level, and the effect on commodity prices of a binding cellulosic biofuel mandate. Previous research has analyzed the potential amount of biomass that can be produced (Heaton et al., 2008; Perlack and Stokes, 2011) as well as traced the supply curves (Khanna et al., 2011a) but have not evaluated the feedstock composition and the effects at the county-level under endogenous crop prices.

The legal basis for the development of biofuels at the federal level is the Energy Independence and Security Act (EISA) of 2007. It fosters the production of corn ethanol with the Renewable Fuel Standard (RFS) which establishes that "transportation fuel sold or introduced into commerce in the United States [... contains at least the applicable volume of renewable fuel" (EISA, 2007). The applicable volume of renewable fuel established by the RFS increases to 136 billion liters in 2022. Beginning 2010, the RFS requires the production of advanced biofuels from cellulosic feedstocks to reach 60 billion liters or $44 \%$ of renewable fuel production by 2022 and includes an allowable maximum of 56 billion liters of corn ethanol after 2015 (Khanna et al., 2011a). According to the Energy Information Administration (EIA), the 2011 U.S. consumption of ethanol was 48.7 billion liters which represents $9.6 \%$ of gasoline by volume and thus, is close to the $10 \%$ blending limit approved for motor vehicles (EIA, 2012). Over the last years, the growth of corn ethanol production slowed down because the federal blenders credit ("Volumetric Ethanol Excise Tax Credit") and the ethanol import tariff expired 2011 as well as a production level coming close to the 2015 RFS requirement of 56 billion liters (FAPRI, 2012).

In addition to the EISA of 2007, federal policy proposals such as the American Clean Energy and Security Act of 2009 and the American Power Act of 2010 have been presented to create a cap-and-trade system in the United States. Both proposals would have affected the market for biomass production because renewable energy credits can be earned from co-firing biomass in coalpower plants. Although neither federal cap-and-trade bills passed, 29 U.S. states have enacted a renewable portfolio standard (RFS) requiring electricity producers to generate a pre-determined level of power from renewable sources including biomass (Dumortier, 2013a). From an energy security and political standpoint, the use of biomass for transportation fuels as opposed to cofiring is more popular because of the abundance of coal in the United States. Although the U.S. Environmental Protection Agency proposed a plan to cut carbon emissions from power plants, which would increase the interest of biomass co-firing in the long-run (EPA, 2014).

Currently, the development of a cellulosic biofuel industry in the U.S. faces significant uncertainty due to economic (Babcock et al., 2011; Khanna et al., 2011a) and political issues (Meyer and Thompson, 2012). The high cost of cellulosic ethanol cannot be reduced without advances in the collection and transportation of biomass as well as conversion technologies (Babcock et al., 2011). Babcock et al. (2011) argue that cellulosic ethanol cannot compete with conventional ethanol and regular gasoline due to high costs and hence, a cellulosic industry is unlikely to emerge without government subsidies. The Food and Agricultural Policy Research Institute (FAPRI) projects the mandate for the production of cellulosic ethanol to be waived and/or reduced in the future because 


\begin{tabular}{cllcc}
\hline Scenario & Scenario Name & Data Source & Switchgrass & Miscanthus \\
\hline S1 & BTS Low Input (SG) & Jager et al. (2010) & $\bullet$ & \\
S2 & BTS High Input (SG) & Jager et al. (2010) & $\bullet$ & \\
S3 & SWAT Low Input (SG) & Baskaran et al. (2010) & $\bullet$ & \\
S4 & SWAT High Input (SG) & Baskaran et al. (2010) & $\bullet$ & \\
S5 & BioCro Low Input (SG) & Miguez et al. (2012) & $\bullet$ \\
S6 & BioCro High Input (SG) & Miguez et al. (2012) & $\bullet$ & \\
S7 & BioCro Low Input (MS) & Miguez et al. (2012) & & $\bullet$ \\
S8 & BioCro High Input (MS) & Miguez et al. (2012) & & $\bullet$ \\
\hline
\end{tabular}

Table 1: Scenarios description

of insufficient capacity (FAPRI, 2012). The repeated waiver of the cellulosic mandate increases the uncertainty about the future policy for advanced biofuels (Meyer and Thompson, 2012). Only a limited number of refineries have been put in place and the spatial locations of cellulosic ethanol plants are yet to be determined.

Previous studies quantifies regional U.S. production patterns (Perlack and Stokes, 2011; Mabee et al., 2011) and supply curves (Khanna et al., 2011a; Walsh et al., 2003) of biomass feedstocks. The work by Perlack and Stokes (2011), also known as the Billion-Ton-Study (BTS), characterizes biomass supply at the county level but without reporting crop price effects. Incorporating crop price effects is important because they affect the opportunity costs of changing from conventional crops such as corn and soybeans to bioenergy crops. Heaton et al. (2008) argue that the biofuel mandate in the U.S. can be met with miscanthus alone based on the harvestable biomass though their analysis neither incorporates the cost of producing miscanthus nor the opportunity cost associated with growing the perennial grass. Our study fills this gap by incorporating price effects of planting miscanthus to fulfill the cellulosic ethanol requirement. We focus on biomass production from agricultural residues, switchgrass, and miscanthus. We report the effects of collecting agricultural residues and growing bioenergy crops on the feedstock mix for cellulosic ethanol production, cropland allocation at the county level, and commodity prices. Although there are important greenhouse gas implications whether agricultural residues or bioenergy crops are used for biomass production, we only focus on biomass production for energy purposes but address the issue in the discussion of our results (Liska et al., 2014).

\section{Materials and Methods}

To model the production of biomass from agricultural residues and bioenergy crops at the county level, we impose a cellulosic biofuel mandate and calculate the resulting biomass price which is necessary to meet the mandate. Based on this farmgate price, the landowner decides how much biomass to produce. We concentrate on the area of three major field crops (corn, soybean, and wheat) as potential acreage of corn stover, wheat straw, switchgrass, or miscanthus. We also allow for pasture to be brought into bioenergy crop production. The three crops represent almost $69 \%$ of total field crop area in the U.S. in 2013 and are important feed and food commodities in addition of having the potential to provide biomass in the case of corn and wheat. We run eight different 
scenarios to analyze the effects of biomass production on the cellulosic feedstock mix. For each scenario, we vary the cellulosic biofuel mandate from 15 to 60 billion gallons in 15 billion gallons increments and assess the availability of pasture on the results. The 60 billion liters is equivalent to the total 2022 cellulosic mandate. An overview of the scenarios is given in table 1 .

Currently, there is no price on biomass for bioenergy production and thus, landowners do not make crop residues available but will be in the future if the current RFS is enforced (Khanna et al., 2011a). Harvesting crop residues should have small effects on the land allocation decision of farmers and should not result in higher commodity prices which makes it attractive to contribute to the renewable energy mix. There are two reasons why significant land-use change could occur. First, if the biomass price is high enough, farmers might find it profitable to change from conventional crops to bioenergy crops which would subsequently lead to higher food prices and indirect land-use change. Second, if there are not sufficient agricultural residues available to cover the mandate, perennial grasses need to be put into production to cover the difference. The two reasons are linked in the sense that a high biomass price would result if agricultural residues are not sufficient to cover the mandate.

Babcock et al. (2011) raise concerns about the existence of a national biomass price because high transportation costs contribute to the existence of price differences across space which is especially true with cellulosic ethanol plants and/or co-firing power plants in place. Khanna et al. (2011a) and Perlack and Stokes (2011) use a national price on biomass to simulate supply patterns. Because the goal of this paper is to simulate the effects of biomass production on cellulosic feedstock mix and area allocation, we remain with this assumption of a national price and assume that it represents an incentive payment to produce biomass for energy production. However, once cellulosic ethanol plants are put online or a co-firing requirement is enacted, we expect a local biomass price to emerge. For each scenario, we impose four different binding biofuel mandates ranging from 15 to 60 billion liters increasing in 15 billion liter steps and assess the effects of pasture availability on the results. The model is calibrated to 2022 expected yield, demand, and baseline prices.

The subsequent sections will cover the model calibration for the field crops (corn, soybean, and wheat), the agricultural residues (corn stover and wheat straw), and the two bioenergy crops (switchgrass and miscanthus). A detailed description of the economic model and the parametrization can be found in supporting information S1 and S2 and we limit the exposition of the economic model to the general framework which is similar to (Dumortier, 2013b).

Depending on the price of biomass, the landowner harvests agricultural residues and/or changes to the production of bioenergy crops. We assume a representative landowner in each county who makes the decisions in terms of land allocation and production given crop and biomass prices. We calculate a biomass price that results in the production of cellulosic feedstock sufficient to fulfil the exogenous cellulosic biofuel mandate. The only exogenous variable in our model is the cellulosic biofuel mandate. The commodity and biomass prices are determined endogenously in our model. Agriculture is a perfectly competitive market and hence, all agents are price takers and do not take the effect of their acreage decision on output prices into account. The crop residue from corn and wheat can be harvested for corn stover and wheat straw. There are six decision variables for landowner: the area allocated to the three crops, the corn and wheat area harvested for residues, and the area allocated to the bioenergy crop.

We assume a lifespan of 10 and 15 years for switchgrass and miscanthus, respectively. As in previous literature, we annualize all the costs to obtain yearly operating cost (Perrin et al., 2008; Jain et al., 2010). We calculate the net present value of all the operating cost by assuming a 


\begin{tabular}{lrrrrrr}
\hline & & \multicolumn{2}{c}{ Nutrient Content $\left(\mathrm{kg} \mathrm{t}^{-1}\right)$} & & \multicolumn{2}{c}{ Cost $\left(\$ \mathrm{t}^{-1}\right.$ removed $)$} \\
Fertilizer & Cost $\left(\$ \mathrm{~kg}^{-1}\right)$ & Corn Stover & Wheat Straw & & Corn Stover & Wheat Straw \\
\hline $\mathrm{N}$ & $\$ 0.94$ & 7.95 & 6.00 & & $\$ 7.47$ & $\$ 5.64$ \\
$\mathrm{P}$ & $\$ 1.53$ & 2.95 & 1.58 & & $\$ 4.50$ & $\$ 2.40$ \\
$\mathrm{~K}$ & $\$ 1.12$ & 15.00 & 10.75 & & $\$ 16.75$ & $\$ 12.00$ \\
\hline Total & & & & $\$ 28.72$ & $\$ 20.05$ \\
\hline
\end{tabular}

Table 2: Nutrient replacement for corn stover and wheat straw

discount rate of $4 \%$ as used in previous studies (Khanna et al., 2008; Jain et al., 2010).

\subsection{Corn, Soybean, and Wheat Production}

Our model includes three field crops (corn, soybeans, and wheat) and covers all counties in the contiguous U.S. that are engaged in the production of at least one of the crops. For the three field crops, the landowner faces demand function, which is a function of the commodity prices and the conventional biofuel production level. We only include corn ethanol as the conventional biofuel in our model. For each crop, there are three demand sectors: consumer/food, feed, and export.

The baseline model, in the absence of any biomass production, is calibrated to 2022 in terms of commodity prices, demand, yield, and area. The prices and price elasticities for food, feed, and export for the demand are taken from FAPRI (2011) and Chen (2010). We use the 2022 crop prices and demand quantities from FAPRI (2013) as well as the use of 5.558 billion bushels (or 141.22 million metric tons) of corn for ethanol production. A market for residues will influence planting decisions, especially for additional corn, when the price of production approaches the cost of production. Our elasticities do not include this effect because it has not yet been observed or empirically verified.

The county-level area harvested is obtained from the National Agricultural Statistics Service (NASS) for 2008-2012. Yield and area by crop and county are set to zero if crop production occurred in less than two years between 2000 and 2010. The base area is the average crop area harvested between 2000 and 2010 corrected to match total domestic use and exports in 2022 . We use the 2022 expected yields by crop and county from the University of Missouri Food and Agricultural Policy Research Institute Farm Cost and Return Tool (FAPRI CART) to determine the yield parameter by county and crop used in our simulation.

Besides the expected yield, FAPRI CART provides cost and return classified according to the USDA Economic Research Service Farm Resources Regions. We use the FAPRI CART parameters on operating cost by crop and farm resource region for 2022 and set the cost per hectare per county equal to the total operating cost composed of chemicals, custom operations, fertilizer, energy (i.e., fuel, lube, and electricity), interest on operating capital, repairs, seeds, and miscellaneous costs. If acreage is increased, we assume that more inputs are needed per hectare resulting in increasing marginal cost. The increase in marginal cost might be due to a increase in fertilizer use or a reduction in yields because of decreasing land quality (Mallory et al., 2011). 


\subsection{Corn Stover and Wheat Straw Production}

Crop residues help control soil erosion and maintain soil carbon and nutrient levels (Perlack and Stokes, 2011). Thus, only a fraction of crop residues can be sustainably removed. Perlack and Stokes (2011) report sustainable retention coefficients for corn stover and wheat straw at the county-level under reduced-tillage and no-tillage. The sustainable retention coefficient is an important factor in determining the biomass yield for crop residues as well as the associated production costs. For the purpose of this analysis, we do not take into account the uncertainty associated with the removal coefficient. We use the reduced-tillage rate and assume that there is no effect on the crop yield when compared to full tillage which is currently practiced for corn production in the Midwest. This is a limitation of the current analysis but justified by the uncertainty of yield estimates under different tillage systems at the national scale. This implicitly assumes that the nutrient replacement is sufficient to keep the yield unchanged. This will subsequently underestimate the amount of corn stover and wheat straw available for cellulosic biofuel production. The removal coefficients together with the residue to grain ratio and the energy content determines the county-specific value of $\delta_{i j}$ for agricultural residues.

The cost associated with corn stover and wheat straw production is composed of nutrient replacement, harvest operations, and storage (Perrin et al., 2008; Thompson and Tyner, 2014). The amount of nutrients that are removed with the harvest of corn stover and wheat straw have to be replaced with additional application of nitrogen $(\mathrm{N})$, phosphorus $(\mathrm{P})$, and potassium $(\mathrm{K})$. The nutrient values for corn stover are taken from Brechbill et al. (2011). The Michigan State University Extension estimates the nutrient value of wheat straw to be $6.5,1.65$, and $11.5 \mathrm{~kg}$ for $\mathrm{N}, \mathrm{P}_{2} \mathrm{O}_{5}$, and $\mathrm{K}_{2} \mathrm{O}$, respectively (MSU Extension, 2013). The Ohio State University Extension estimates the nutrient value of wheat straw to be 5.5, 1.5, and $10 \mathrm{~kg}$ for $\mathrm{N}, \mathrm{P}_{2} \mathrm{O}_{5}$, and $\mathrm{K}_{2} \mathrm{O}$, respectively (OSU Extension, 2012). The mean of those values is represented in table 2. The fertilizer prices for $N$ (anhydrous ammonia), $P$ (super-phosphate), and $K$ (potassium chloride) are the average for the years 2010 to 2012 from the USDA ERS Fertilizer Use and Prices database (USDA Economic Research Service, 2011). Note that the cost of phosphate almost doubled since 2006 which increases the cost of nutrient replacement in our analysis by approximately $8.38 \$ \mathrm{t}^{-1}$ and $6.00 \$ \mathrm{t}^{-1}$ for corn stover and wheat straw, respectively.

Harvest operations for agricultural residues consists of raking and baling. The cost of raking and bailing is taken from Chen (2010) who collected state-level harvest costs from university extension services. The harvest cost per ton associated with residue removal declines with yield (Perlack and Stokes, 2011). Perrin et al. (2008) calculates cost ranging from 45.55 to $48.35 \$ \mathrm{t}^{-1}$ for shredding, raking, baling, and nutrient replacement. This is consistent with $47.87 \$ \mathrm{t}^{-1}$ (2012 \$) calculated by Thompson and Tyner (2014). Sesmero and Gramig (2013) find cost estimates of $27.58 \$ \mathrm{t}^{-1}$ and $28.74 \$ \mathrm{t}^{-1}$ for a corn-soybean and continuous corn rotation, respectively. The authors budget the on-farm storage cost (including storage loss) with $4.75 \$ \mathrm{t}^{-1}$ and $5.79 \$ \mathrm{t}^{-1}$ for a corn-soybean and continuous corn rotation, respectively. Note that Sesmero and Gramig (2013) do not include nutrient replacement based on recent agronomic research which indicates that there might be no negative yield impact from removing agricultural residues. A storage loss in dry matter of $6 \%$ is included in our calculations.

If the farmer removes crop residue, a switch to reduced tillage or no-till might be necessary. Estimates on the cost savings due to no-till vary significantly from $1.7 \$ \mathrm{ha}^{-1}$ (Sesmero and Gramig, 2013) to $61.78 \$ \mathrm{ha}^{-1}$ (Thomson et al., 2009). The analysis by Sesmero and Gramig (2013) assumes that extra herbicides need to be applied under the no-till scenario. Because of significant uncertainty 


\begin{tabular}{|c|c|c|c|c|c|}
\hline \multirow[b]{2}{*}{ Item } & \multirow[b]{2}{*}{ Unit Cost } & \multicolumn{2}{|c|}{ Low Cost } & \multicolumn{2}{|c|}{ High Cost } \\
\hline & & Year 1 & Rest & Year 1 & Rest \\
\hline Seed Switchgrass $\left(\mathrm{kg} \mathrm{ha}^{-1}\right)$ & $\$ 22.31$ & 6.50 & - & 11.00 & - \\
\hline Nitrogen $\left(\mathrm{kg} \mathrm{ha}^{-1}\right)$ & $\$ 0.94$ & - & 56 & - & 140 \\
\hline Phosphorus $\left(\mathrm{kg} \mathrm{ha}^{-1}\right)$ & $\$ 1.53$ & 33.70 & - & 33.70 & - \\
\hline Phosphorus $\left(\mathrm{kg} \mathrm{t}^{-1}\right)$ & $\$ 1.53$ & - & 0.42 & - & 0.97 \\
\hline Potassium $\left(\mathrm{kg} \mathrm{ha}{ }^{-1}\right)$ & $\$ 1.12$ & 44.90 & - & 44.90 & - \\
\hline Potassium $\left(\mathrm{kg} \mathrm{t}^{-1}\right)$ & $\$ 1.12$ & - & 9.47 & - & 11.40 \\
\hline Lime $\left(\mathrm{t} \mathrm{ha}^{-1}\right)$ & $\$ 57.50$ & - & - & 6.70 & - \\
\hline Atrazine (liters ha ${ }^{-1}$ ) & $\$ 4.66$ & 3.50 & - & 3.50 & 3.50 \\
\hline 2,4-D (liters ha $\left.{ }^{-1}\right)$ & $\$ 5.32$ & 1.80 & 1.80 & 1.80 & 1.80 \\
\hline Pre-harvest Operations $\left(\$ \mathrm{ha}^{-1}\right)$ & & 62.14 & 24.86 & 62.14 & 24.86 \\
\hline Staging and Loading $\left(\$ \mathrm{t}^{-1}\right)$ & & - & 9.72 & - & 9.72 \\
\hline Storage $\left(\$ t^{-1}\right)$ & & - & 4.65 & - & 4.65 \\
\hline Total cost $\left(\$ \mathrm{ha}^{-1}\right)$ & & $\$ 334.60$ & $\$ 87.06$ & $\$ 820.25$ & $\$ 182.29$ \\
\hline Total cost $\left(\mathrm{t}^{-1}\right)$ & & & $\$ 25.59$ & & $\$ 28.58$ \\
\hline
\end{tabular}

Table 3: Production cost for switchgrass. The re-seeding cost for the low and high input parametrization are not reported in this table but can be found in the supporting information S1

involved with the switch to no-till in terms of effect on yield, we only provide a break-even prices for corn stover and wheat straw for the reduced tillage scenario assuming that there is no effect on yield.

\subsection{Bioenergy Crop Production}

We consider switchgrass (Panicum virgatum) and miscanthus (Miscanthus $x$ giganteus) as the possible sources for bioenergy. There is significant uncertainty about the yield of those bioenergy crops because they are not grown at a commercial level in the United States. To assess the uncertainty from switchgrass yields, we use three data sources from previous literature. The first estimates are used in the Billion-Ton-Study (BTS) by Perlack and Stokes (2011) and predict county level yield by fitting an empirical model to observed field trials (Jager et al., 2010). The work by Baskaran et al. (2010) provides the second switchgrass yield data set consisting of simulated yields using the Soil and Water Assessment Tool (SWAT). As reported by Baskaran et al. (2010), there can be significant differences among estimated switchgrass yields across the United States because large scale plantation has not yet occurred and thus, yields at the county level are unknown. Baskaran et al. (2010) evaluate lowland yields and to allow for comparison of the scenarios, only the lowland yields from Jager et al. (2010) are used.

The differences between the two yield data sets can be categorized in four large regions: The only region where the Baskaran et al. (2010) model predicts higher yields per ha is in the southern part of Texas with a yield difference ranging between 1.5 to 2.5 tons per hectare. The data by Jager et al. (2010) predicts higher yields in a strip ranging from Western parts of Texas to Western Kansas. 


\begin{tabular}{|c|c|c|c|c|c|}
\hline \multirow[b]{2}{*}{ Item } & \multirow[b]{2}{*}{ Unit Cost } & \multicolumn{2}{|c|}{ Low Cost } & \multicolumn{2}{|c|}{ High Cost } \\
\hline & & Year 1 & Rest & Year 1 & Rest \\
\hline Seed Miscanthus (rhizome ha ${ }^{-1}$ ) & $\$ 0.25$ & 10,000 & - & 10,000 & - \\
\hline Nitrogen $\left(\mathrm{kg} \mathrm{ha}^{-1}\right)$ & $\$ 0.94$ & 30 & 50 & 60 & 130 \\
\hline Phosphorus (kg ha-1) & $\$ 1.53$ & 7 & - & 7 & - \\
\hline Phosphorus $\left(\mathrm{kg} \mathrm{t}^{-1}\right)$ & $\$ 1.53$ & - & 0.30 & - & 1.10 \\
\hline Potassium $\left(\mathrm{kg} \mathrm{ha}^{-1}\right)$ & $\$ 1.12$ & 100 & - & 100 & - \\
\hline Potassium $\left(\mathrm{kg} \mathrm{t}^{-1}\right)$ & $\$ 1.12$ & - & 0.80 & - & 1.20 \\
\hline Lime $\left(\mathrm{t} h \mathrm{~h}^{-1}\right)$ & $\$ 57.50$ & 2.30 & - & 4.50 & - \\
\hline Atrazine $\left(\mathrm{L} \mathrm{ha}^{-1}\right)$ & $\$ 4.66$ & 3.50 & - & 3.50 & - \\
\hline $2,4-\mathrm{D}\left(\mathrm{L} \mathrm{ha}{ }^{-1}\right)$ & $\$ 5.32$ & 1.80 & - & 1.80 & - \\
\hline Pre-harvest Operations $\left(\$ \mathrm{ha}^{-1}\right)$ & & 184.64 & 24.86 & 184.64 & 24.86 \\
\hline Staging and Loading $\left(\$ \mathrm{t}^{-1}\right)$ & & - & 8.65 & - & 8.65 \\
\hline Storage $\left(\$ t^{-1}\right)$ & & - & 4.65 & - & 4.65 \\
\hline Total cost $\left(\$ \mathrm{ha}^{-1}\right)$ & & $\$ 2,993.29$ & $\$ 71.85$ & $\$ 3,147.98$ & $\$ 147.03$ \\
\hline Total cost $\left(\$ t^{-1}\right)$ & & & $\$ 14.65$ & & $\$ 16.32$ \\
\hline
\end{tabular}

Table 4: Production cost for miscanthus. The re-seeding cost for the low and high input parametrization are not reported in this table but can be found in the supporting information S1

Higher yield difference between $4-8 \mathrm{t} \mathrm{ha}^{-1}$ are observed in the region ranging from the Eastern part of Iowa all the way to Pennsylvania. The last region where the BTS yields are significantly higher are in the Appalachian mountains. The analysis by Miguez et al. (2012) provide the last switchgrass estimates as well as the miscanthus yield estimates used in out work.

The cost of production for switchgrass and miscanthus is composed of seeding (including reseeding), fertilizer (nitrogen, phosphorus, and potassium), lime, herbicides, pre-harvest operations, harvesting, and storage. There are a variety of estimates about the fertilizer, harvest, staging and loading, and storage needs for switchgrass and miscanthus plantations in the literature and Khanna et al. (2008) provide an excellent review on the agronomic assumption for the production of switchgrass and miscanthus. To determine the upper and lower bound of costs in terms of agronomic inputs, we follow closely Jain et al. (2010), who use minimum and maximum input values in each category to provide lower and upper bounds of agronomic needs. The lower and upper values in Jain et al. (2010) are consistent with Khanna et al. (2008) who compiles lower and upper values from different switchgrass and miscanthus studies. Those values are mostly from field trials in the United States and Europe. Both energy crops have not yet been deployed at a large scale which results in uncertainty about the agronomic input needs. The agronomic assumptions for switchgrass and miscanthus are divided between the establishment year and the post-establishment years. For a detailed breakdown of the cost, see the supporting information S2.

Seeding for switchgrass varies from $6.5 \mathrm{~kg} \mathrm{ha}^{-1}$ (Epplin, 1996) to $11 \mathrm{~kg} \mathrm{ha}^{-1}$ (Lewandowski et al., 2003) with reseeding rates between 15\% (Turhollow, 2000) to 50\% (Duffy and Nanhou, 2001). According to Duffy and Nanhou (2002), the probability of reseeding is $25 \%$ and $50 \%$ for 
frost and spring seeding, respectively. The cost for switchgrass seeds are reported to be $18.78 \$$ $\mathrm{kg}^{-1}$ (Jain et al., 2010). Seeding for miscanthus ranges from 1 to 2 plants $\mathrm{m}^{-2}$ with a $0 \%-50 \%$ reseeding rate (Khanna et al., 2008). We assume a cost of $0.25 \$$ rhizome $^{-1}$. Despite the possibility of needing to plant 2 rhizome per hectare, we do not evaluate the possibility in our model because it would raise the initial cost by $\$ 2,500$ which seems unrealistic that a landowner would spend.

For switchgrass, no nitrogen is applied in the establishment year to avoid competition between switchgrass and weeds (Duffy and Nanhou, 2001; Khanna et al., 2008; Jain et al., 2010). In the subsequent years, application rates vary from $56-140 \mathrm{~kg} \mathrm{ha}^{-1}$ (Khanna et al., 2008; Jain et al., 2010). For the application rates of phosphorus, we use $33.7 \mathrm{~kg} \mathrm{ha}^{-1}$ in the establishment year and 0.42-0.97 $\mathrm{kg} \mathrm{t}^{-1}$ in the post-establishment years. For potassium, we use $44.9 \mathrm{~kg} \mathrm{ha}^{-1}$ in the establishment year and $9.47-11.40 \mathrm{~kg} \mathrm{t}^{-1}$ in the post-establishment years. Those values represent estimates on the amount of $\mathrm{P}$ and $\mathrm{K}$ removed per ton of switchgrass (Duffy and Nanhou, 2001, 2002). Lime application for switchgrass in establishment year ranges from 0-6.7 $\mathrm{t} \mathrm{ha}^{-1}$. For miscanthus, we chose a nitrogen application rate in the establishment year of 30-60 kg ha ${ }^{-1}$ for the low and high input scenarios (Jain et al., 2010). Although Christian et al. (2008) suggest that there is no response of miscanthus yield to nitrogen fertilization, others find positive values to nitrogen application (Lewandowski et al., 2003; Khanna et al., 2008). For post establishment years, values of nitrogen application range from 50-130 $\mathrm{kg} \mathrm{ha}^{-1}$ (Khanna et al., 2008) consistent with the recommendation to replace some of the $\mathrm{N}$-uptake by switchgrass (Christian et al., 2008). The application rates for lime, atrazine, and 2,4-D are taken from Jain et al. (2010) and are assumed to be the same for all states under consideration. Notably, application rates are composed of a fixed rate per hectare and a rate that depends on the biomass yield. National prices for herbicides and pesticides are taken from the U.S. Department of Agriculture (USDA) National Agricultural Statistical Service (NASS) database for 2012. As in Jain et al. (2010), we assume that this uncertainty has no effect on the yield, i.e., the yield in the long-run is unaffected by the nitrogen application rate.

For the pre-harvest operations which consists of seeding and applying fertilizers and herbicides, we use the costs presented in Khanna et al. (2008). The planting of switchgrass involves disking (tandem disk), harrowing, airflow planter (application of seeds, phosphorus, and potassium), and a sprayer (nitrogen and herbicides). The machinery required for the planting of miscanthus consists of a chisel plow, harrow, airflow planter and sprayer, and a potato planter. We assume that costs are valid for all counties and the same for the high and low cost scenarios because we evaluate the effects of agronomic uncertainty.

The harvest operations include mowing, raking, and bailing (square bales). The harvest operations for switchgrass and miscanthus are assumed to be the same as for hay (Brechbill et al., 2011). The cost estimates per state are taken from Chen (2010) who obtained the cost for harvesting hay from state extension services. The costs assume that harvesting of switchgrass and miscanthus is done in a single pass. The cost of staging and loading are taken from Khanna et al. (2008) but were converted to a dollar per ton basis because of differences in bioenergy crop yields.

Due to differences in the energy content of corn stover, wheat straw, and bioenergy crops, we express the biomass price in dollars per gigajoule (GJ). The residue to grain ratio on a dry basis is 1:1 and 1:1.5 for corn stover and wheat straw, respectively (Khanna et al., 2011a; Sesmero and Gramig, 2013). The heating values in giga joules (GJ) per metric ton are 17.69 and 17.659 for corn stover and wheat straw, respectively (ORNL, 2011). As for the corn stover and wheat straw data, the bioenergy crop yields are converted in gigajoules using the value of $18.51 \mathrm{GJ} \mathrm{t}^{-1}$. 


\subsection{Pasture}

Pasture area (no woodland, no cropland) was obtained from the 2012 USDA Census of Agriculture. To determine the upper and lower bound of pasture converted to bioenergy crops, the minimum and maximum county-level cash rent value between 2008 and 2013 were used.

\section{Results}

Our results show that for the 15 and 30 billion L scenarios, agricultural residues cover the entire mandate if the input requirements for bioenergy crops are high. With the exception of the low production input for miscanthus scenario, the share of agricultural residues is always over $50 \%$ to cover the mandate even at 60 billion L scenarios. The largest proportion of agricultural land dedicated to either switchgrass or miscanthus is found in the Southern Plains and the Southeast. It is not profitable in any scenario to grow switchgrass or miscanthus in the Corn Belt even on pasture land. With the exception of two scenarios, only the 45 and 60 billion liter mandates see a large share of bioenergy crops as a feedstock for cellulosic ethanol. Commodity prices changes are moderate for corn and soybeans and reach a maximum of $25 \%$ for wheat. Those price effects are consistent with the finding that little acreage is dedicated to bioenergy crops in the Corn Belt.

Figure 1 illustrates the composition of cellulosic biofuel by feedstock based on the mandate if bioenergy crops are planted on cropland only (corn, soybeans, and wheat area) and on cropland and pasture (Figure 1b). Note that we only allow pasture to be converted to a bioenergy crop but do not have allow for crop expansion. Net returns from pasture are lower than for crop production. This results in a switch from pasture to bioenergy crops in some counties with high biomass production cost before agricultural residues come into production. Because the yield for switchgrass and miscanthus is higher than for agricultural residues, the mandates are met with a larger share of bioenergy crops in the case of pasture conversion. Sesmero and Gramig (2013) state that about 25\% of the mandate will be covered by corn stover. Our results indicate that the share of corn stover is going to be closer to $55 \%$ in the 60 billion L case where only cropland is considered. If pasture used as area for bioenergy crop production, the share is fairly stable at around $50 \%$ except for the scenario "BioCro Low Input (MS)". In that case, the share of agricultural residues close is only around $25 \%$. This result is due to the combination having miscanthus yields that are high and low production cost. Our results suggest that despite the higher yield of switchgrass and miscanthus, agricultural residues will be the primary feedstock for a binding cellulosic biofuel mandate. Also, the use of lower removal coefficients in our model (reduced-tillage instead of no-tillage) most likely underestimates the share of agricultural residues to cover the mandate.

The biomass prices necessary to achieve the mandates are represented in figure 2 . The differences in biomass price between the simulation with pasture and without pasture are small for the 15 and 30 billion L mandate and are within $10 \%$. This is consistent with our previous finding that states that most of the mandate will be met with agricultural residues. So the availability of pasture to plant bioenergy crops does not come into play. The difference in biomass prices is evident for the 45 and 60 billion L mandate for which biomass prices rise on average between $16.04 \%$ and $37.33 \%$, respectively. For those mandates, the availability of pasture helps to reduce the price of achieving the mandate. Also, the price necessary is increasing exponentially in the case of switchgrass when only cropland is available. When pasture is available, the exponential increase in the biomass price is only observed for the high input scenarios. For miscanthus, the price increases to meet the mandate is more gradual. 
(a)

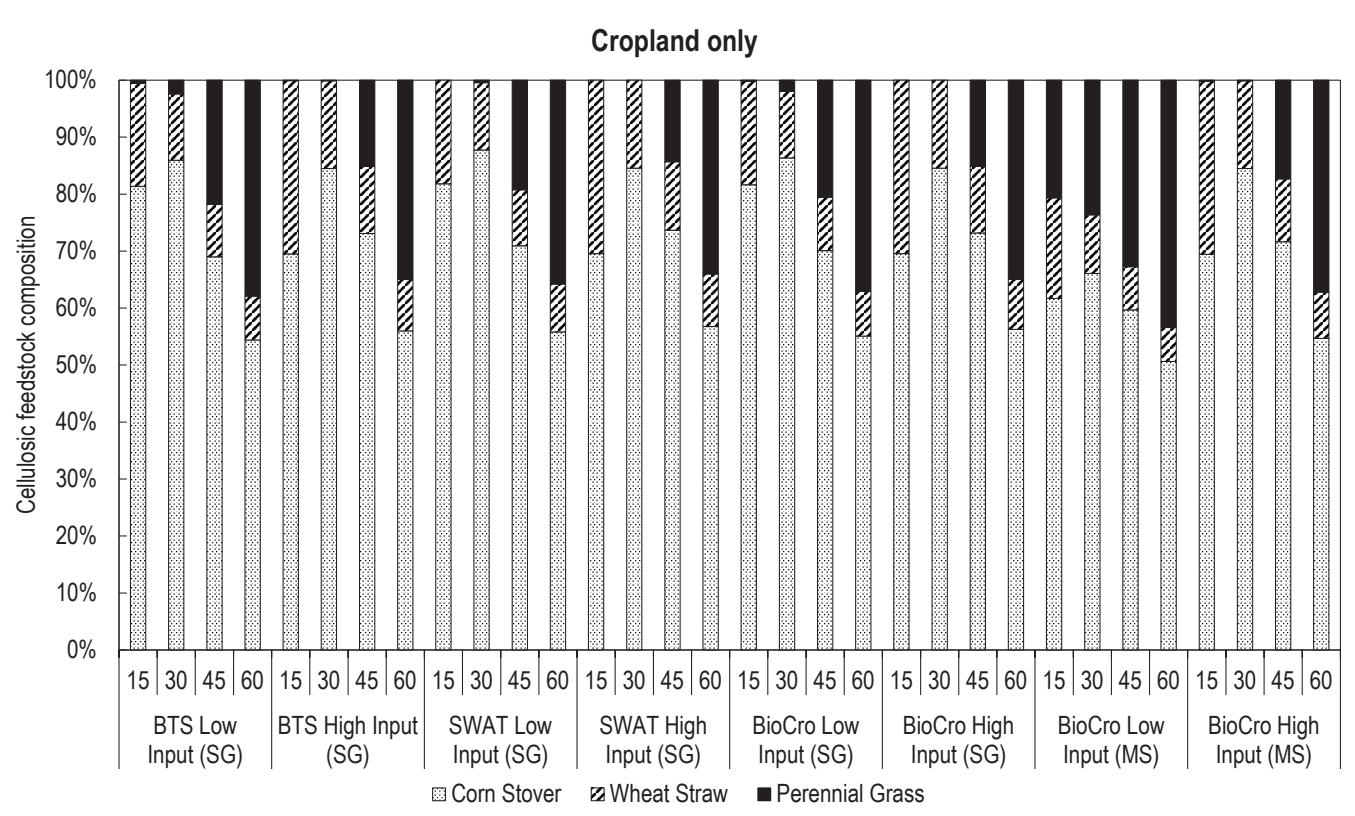

(b)

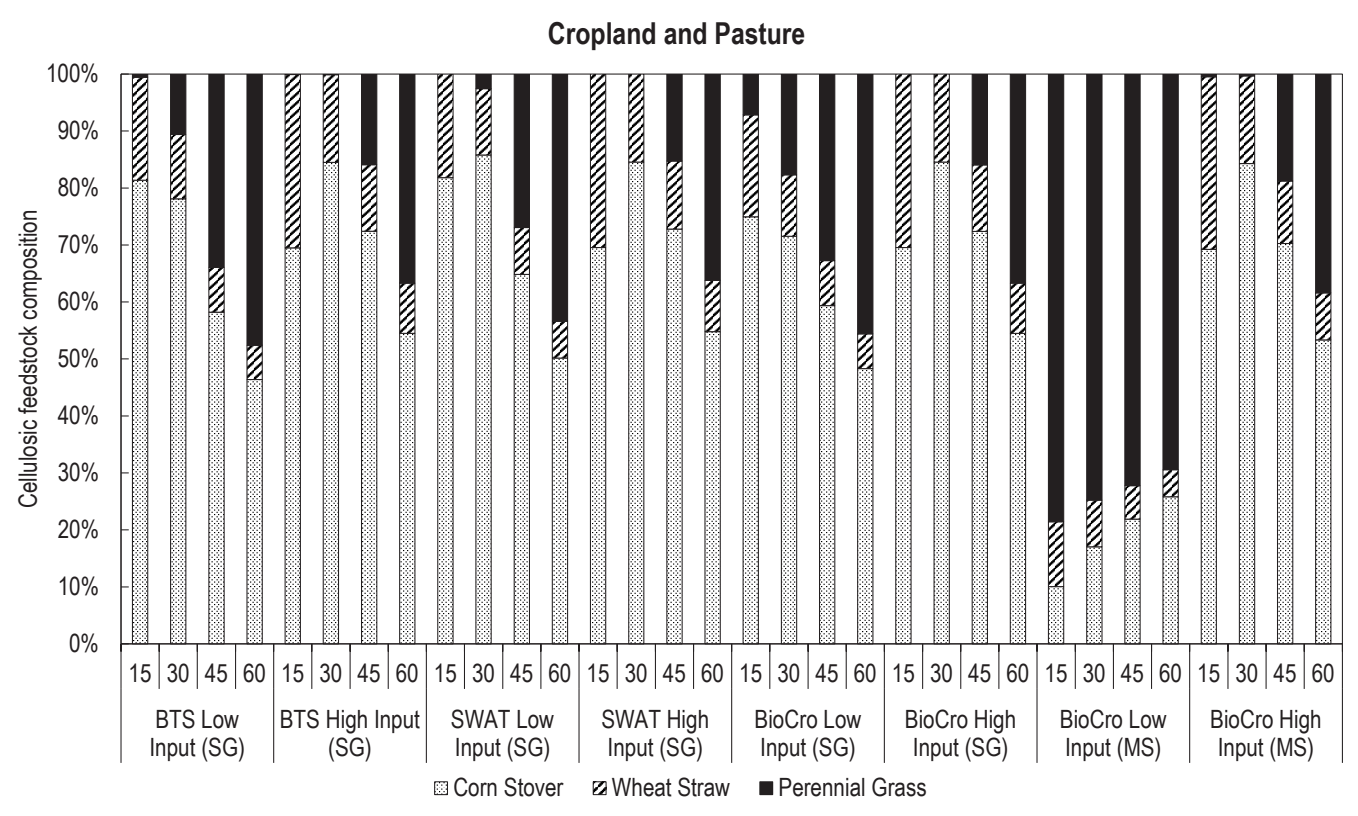

Figure 1: Cellulosic feedstock composition for mandates ranging from 15 to 60 billion L. 
(a)

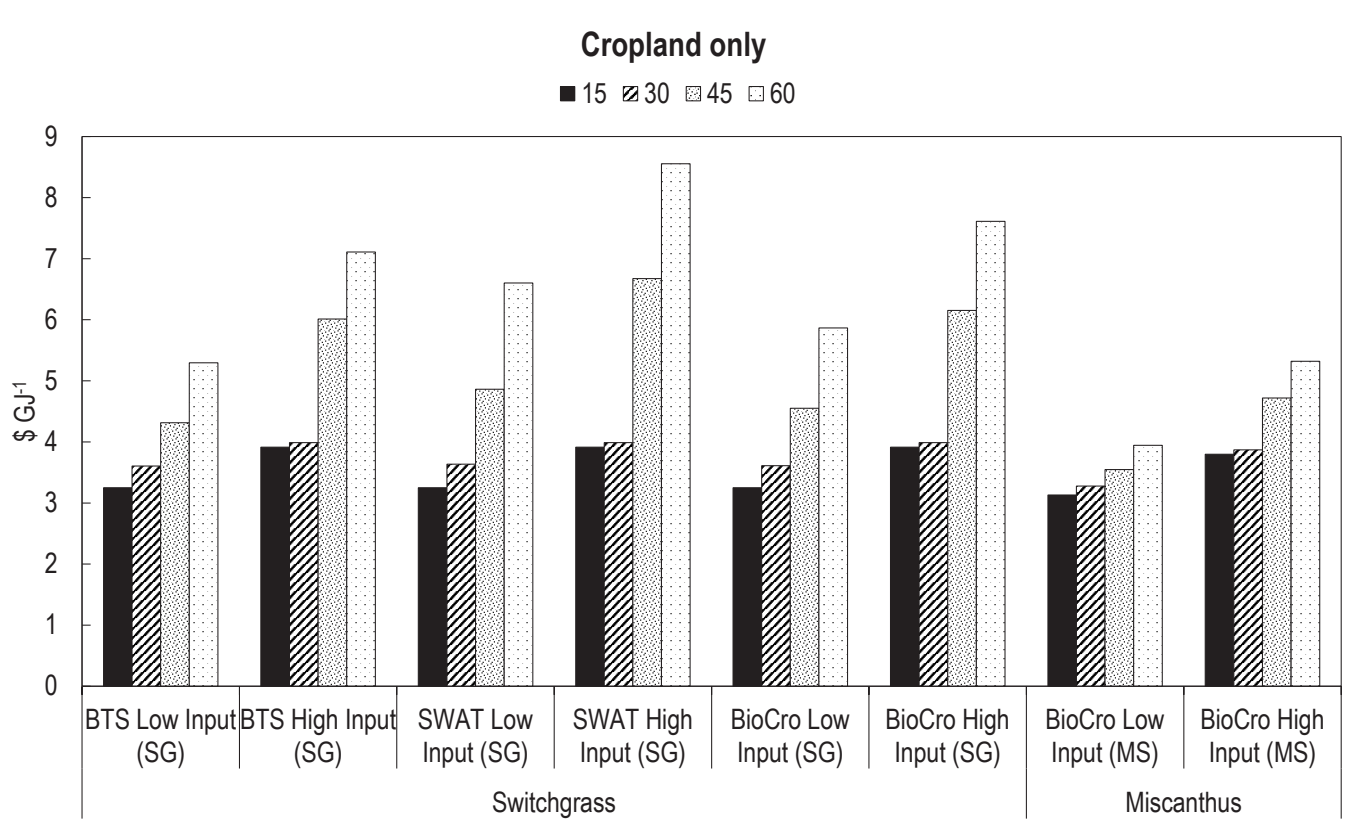

(b)

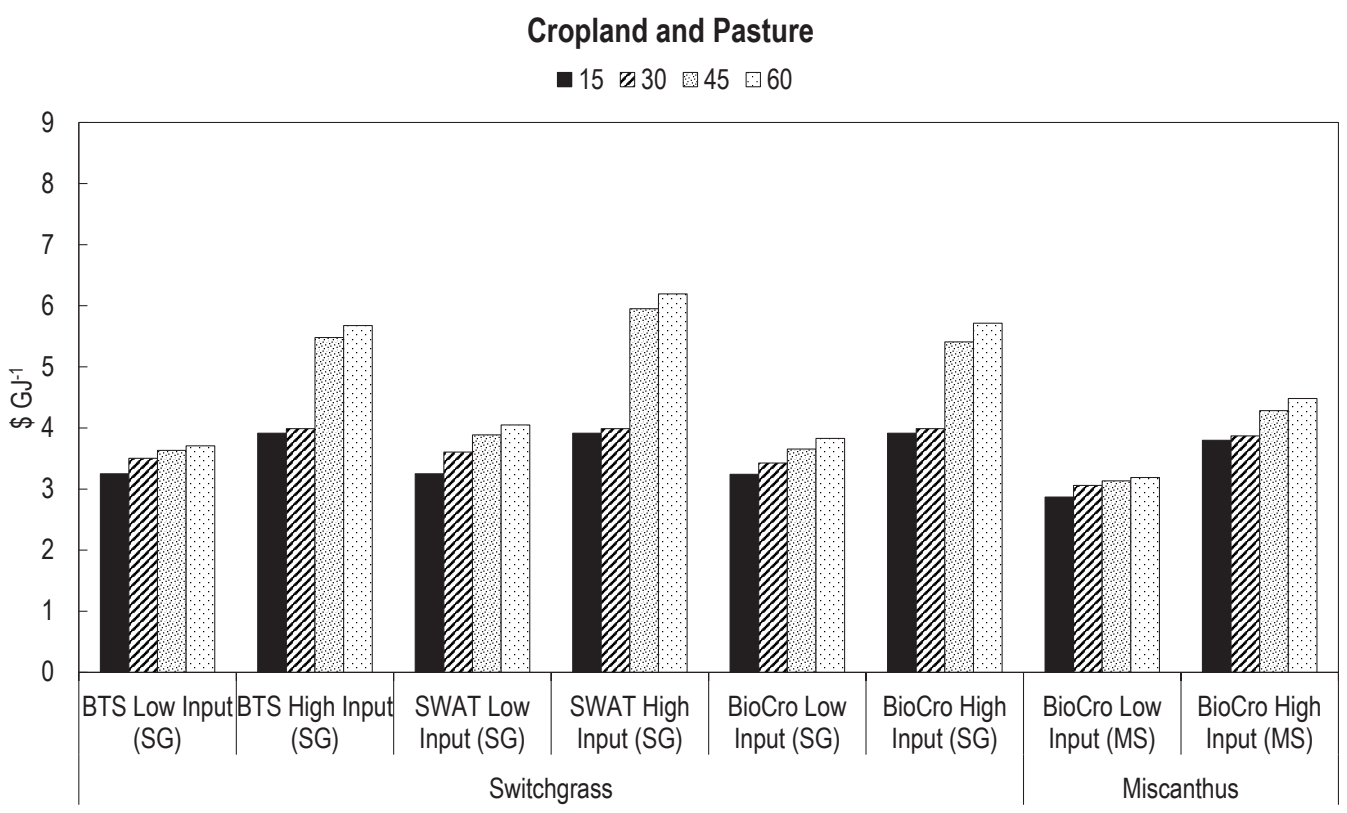

Figure 2: Biomass prices in $\$ \mathrm{GJ}^{-1}$ for mandates ranging from 15 to 60 billion $\mathrm{L}$. 

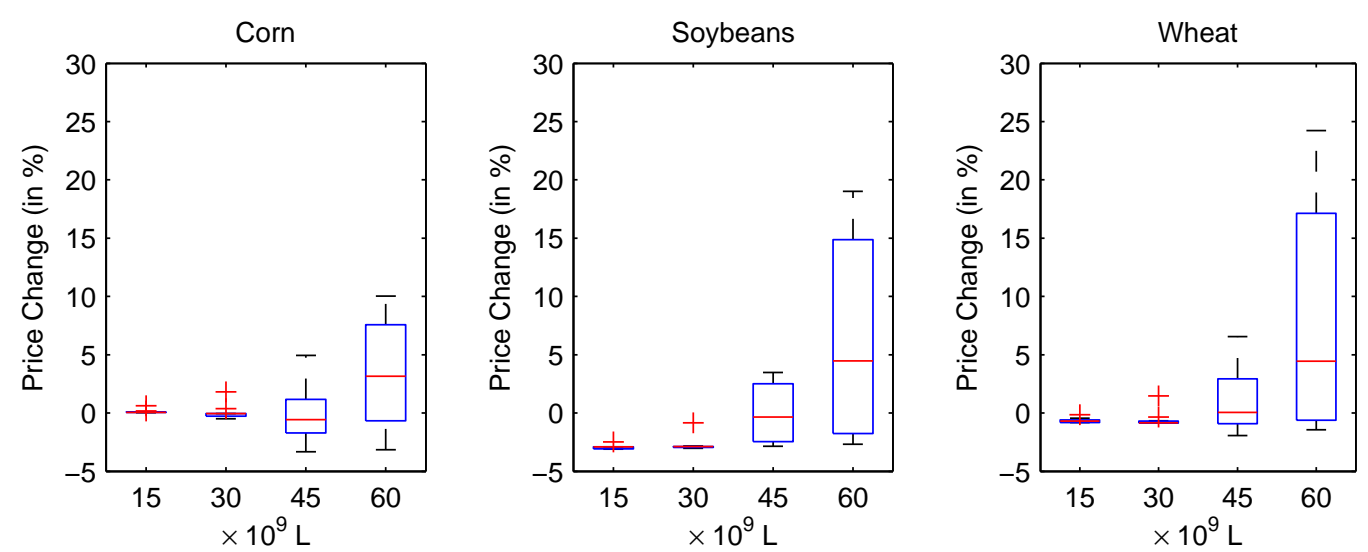

Figure 3: Price increase for corn, soybean, and wheat for mandates ranging from 15 to 60 billion L. The distribution includes all scenarios and the availability of pasture.

The effect on commodity prices as a function of the mandate is represented in figure 3 . The price of corn only increases slightly because landowners planting corn do not have an incentive to switch to either soybean or switchgrass. In some cases, the price of corn decreases because landowners find it profitable to increase the corn area because corn stover provides an additional revenue. Due to the corn ethanol expansion in recent years, land values are already at a very high level. Wheat has a lower profitability compared to corn and despite being able to deliver wheat straw as a biomass, landowners still find it more profitable to change to switchgrass or miscanthus which leads to a reduction in the supply of wheat and thus, to an increase in wheat prices. The same issue arises for soybeans but to a lesser extent. The magnitude of the commodity price increase depends largely on the amount of area dedicated to switchgrass or miscanthus. This is in line with the possibility of commodity prices increasing given a sufficiently high biomass price. It is true that harvesting agricultural residues does not interfere with food and feed production in the absence of cropland conversion to bioenergy crops. Some landowners will find it profitable to grow bioenergy crops instead of conventional crops which results in a decrease in area for corn, soybean, and wheat.

Counties and states in the Corn Belt where corn and soybean are still the more profitable land-uses do not see a large share of bioenergy crops. In figures 4 and 5, we only compare the 60 billion L scenario for the switchgrass and miscanthus yield data estimated by Miguez et al. (2012) because the estimation method for both bioenergy crops is consistently determined by the BioCro model. Note the high share of bioenergy crops in Oklahoma and Eastern Kansas. In those areas, (winter) wheat is grown but the yield is relatively low compared to other wheat growing regions in the country. This is also reflected in the increase in the wheat price. Counties in the Carolinas are changing from conventional crop production to switchgrass. For miscanthus, only crop area in the South Carolina are making the switch. The available area from corn, soybean, and wheat production in those states is small and thus, the impact on commodity prices is as modest as seen. For pasture, a slightly different picture emerges. First, no pasture is converted to bioenergy crops in the Corn Belt in any of our simulations. We only see conversion of pasture to bioenergy crops (switchgrass and miscanthus) in the Southern parts of the country and some conversion in South Carolina. Despite many counties converting from pasture and conventional crop production in the South and the Southeast, the vast majority of biomass is still produced in the Corn Belt as seen 
(a)

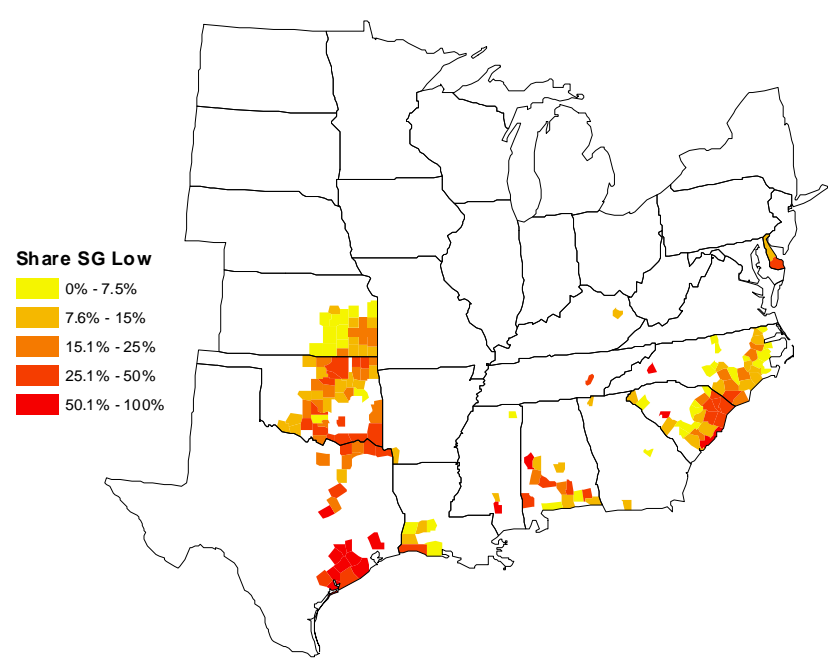

(c) (b)

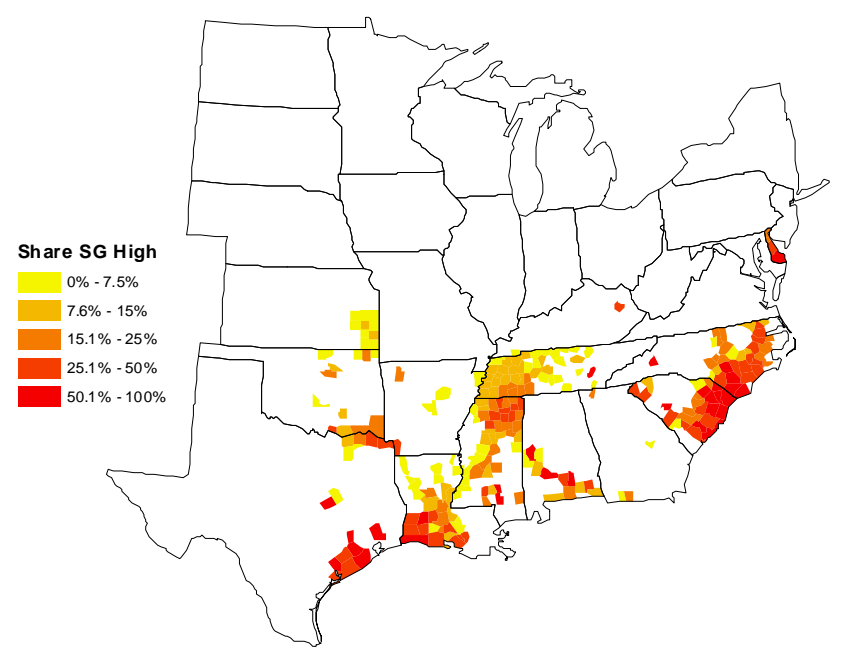

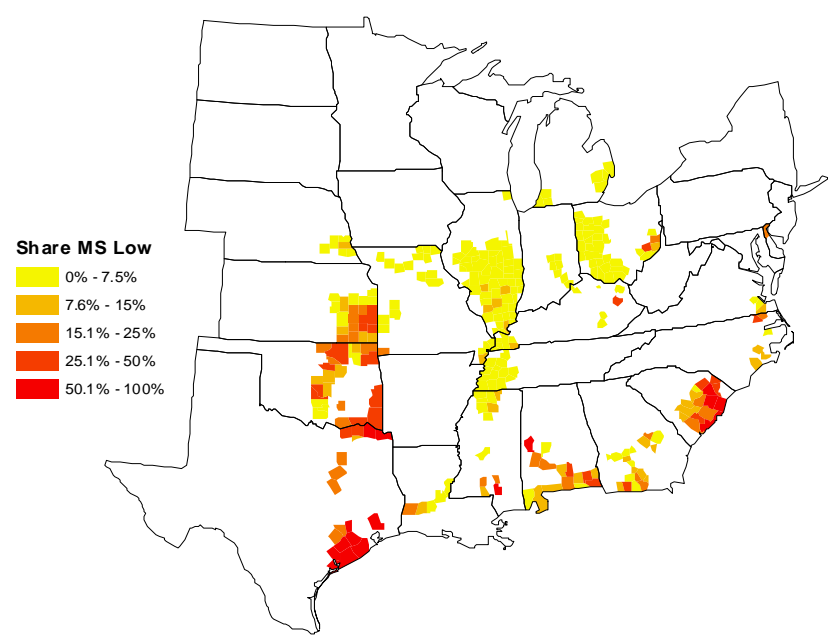

(d)

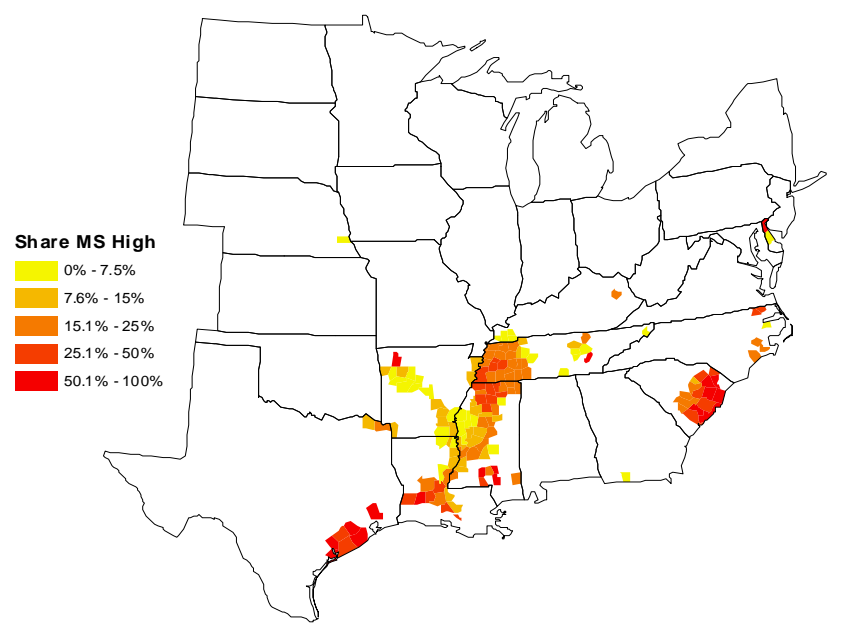

Figure 4: Share of cropland (corn, soybean, and wheat) dedicated to bioenergy crops in the scenarios S5-S8, i.e., "BioCro Low Input (SG)" (Panel (a)), "BioCro High Input (SG)" (Panel (b)), "BioCro Low Input (MS)" (Panel (c)), and "BioCro High Input (MS)" (Panel (d)) under the 60 billion liter mandate and in the presence of pasture. 
(a)

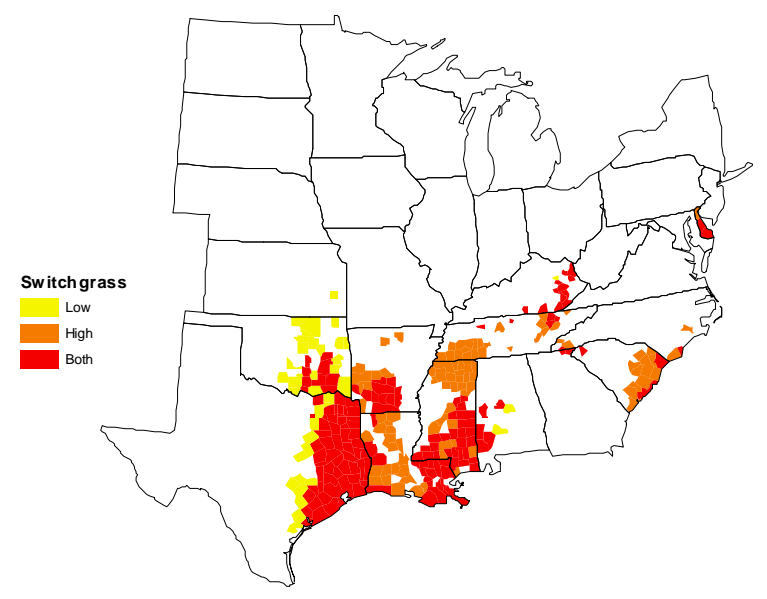

(b)

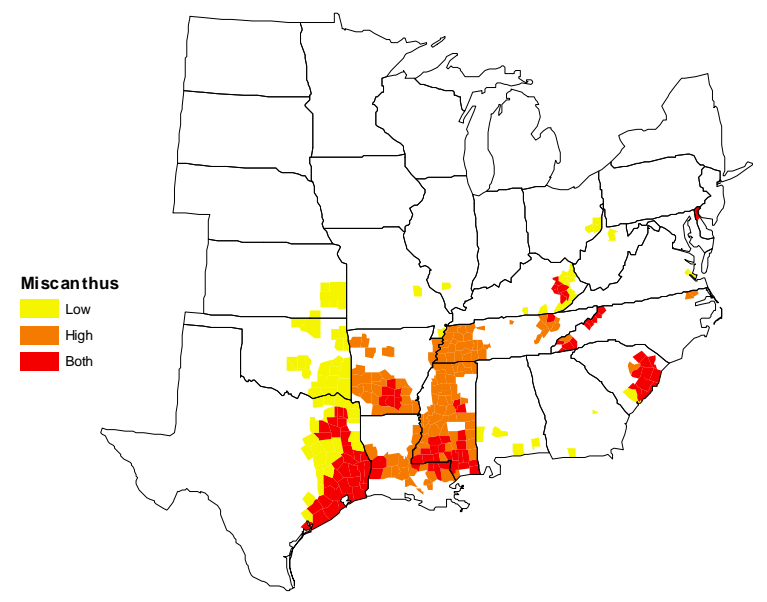

Figure 5: Counties changing from pasture to bioenergy crops for the switchgrass scenarios ("BioCro Low Input (SG)" and "BioCro High Input (SG)") in Panel (a) and the miscanthus scenarios ("BioCro Low Input (MS)" and "BioCro High Input (MS)") in Panel (b) under the 60 billion liter mandate. "Low" refers to counties that switch only in the low input scenario, "High" refers to counties that switch only in the high input scenario, and "Both" refers to counties that switch in both scenarios. 

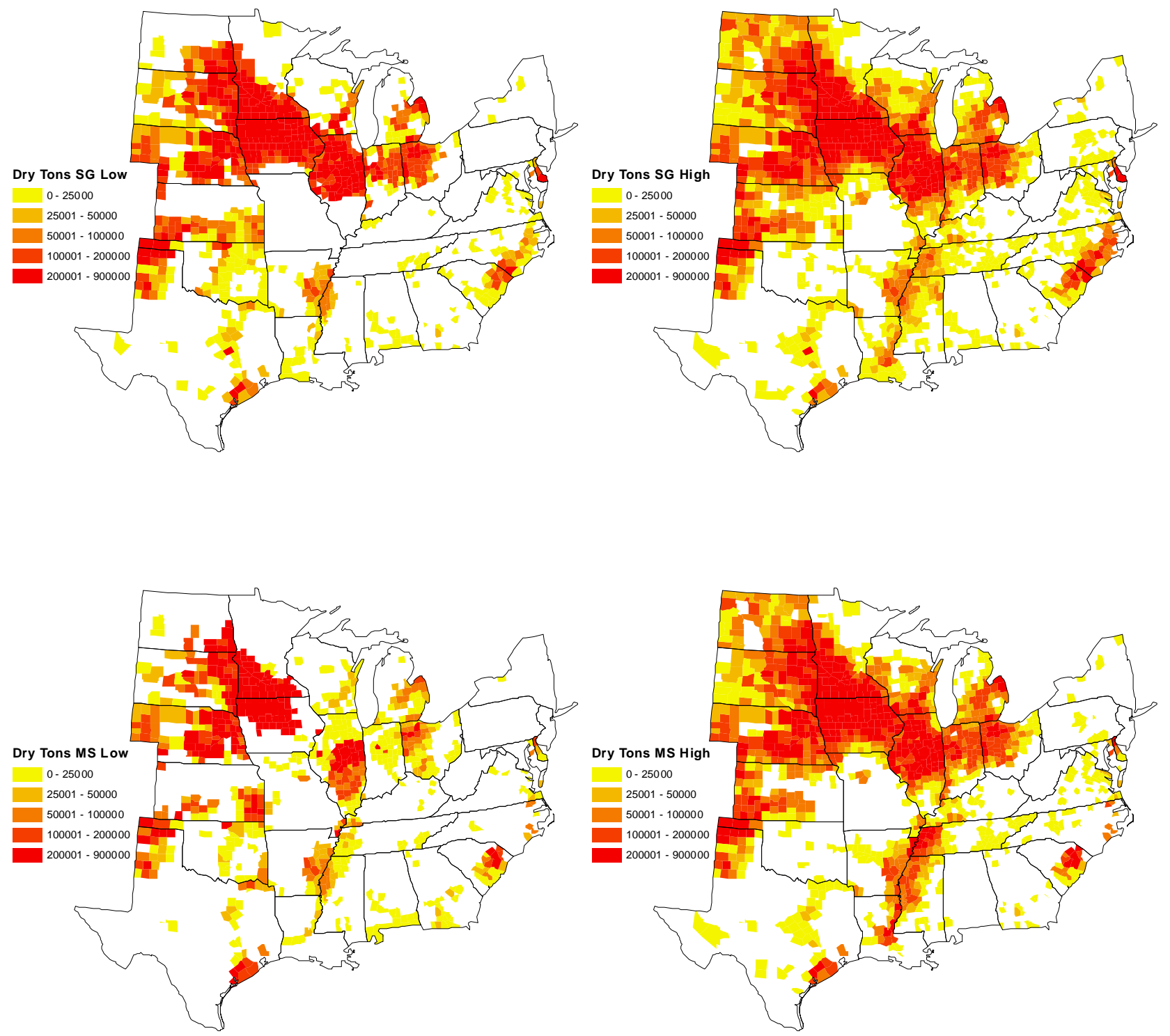

Figure 6: Total supply of biomass in dry tons per county in the scenarios S5-S8, i.e., "BioCro Low Input (SG)" (Panel (a)), "BioCro High Input (SG)" (Panel (b)), "BioCro Low Input (MS)" (Panel (c)), and "BioCro High Input (MS)" (Panel (d)) under the 60 billion liter mandate and in the presence of pasture. 
in figure 6 . The percentage of biomass being produced in 10 Midwestern states ${ }^{1}$ range from $83.3 \%$ - $87.2 \%$. We would expect biofuel plants developing from a cellulosic ethanol industry to emerge close to the area where feedstock is available. The majority of current corn ethanol plants is located in the 10 aforementioned states (USDA, 2012).

\section{Discussion}

The model results indicate that the majority of the cellulosic mandate will likely be covered by agricultural residues. For low mandates, the share of agricultural residues is almost $100 \%$ and only at high mandates of 30 to 45 billion L do we see a large scale introduction of bioenergy crops. Currently, there is no economic incentive for farmers and land owners to produce biomass from agricultural residues or bioenergy crops and the mandate that is in place has been waived for several years. If the mandate is enforced, this analysis provides guidance for appropriate compensations for the farmer based on modeled farmgate biomass prices. Note that the biomass prices calculated in this study would be in addition to the cost of producing corn which can readily serve as a feedstock for corn ethanol.

Our choice of parameters leads to several discussion points that we would like to address in this section. In particular, the higher removal coefficients under no-tillage, planting of bioenergy crops in the south, the cost of switching to bioenergy crops, crop rotation, the use of marginal land, and environmental issues associated with agricultural residues are subject for discussion.

All of our scenarios assume low removal coefficients for agricultural residues. If higher residue removal coefficients are allowed, residues will provide more biofuel feedstock and less switchgrass and miscanthus are necessary to meet the mandate. In the supporting information S1, we present the increase in agricultural residue production cost from moving to the high removal coefficients. This increase needs to be compensated by the additional revenue from biomass production and the savings from the no-tillage practice. It also assumes that nutrient replacement is sufficient to have no effect on bioenergy crop yields.

A related topic with respect to the higher residue removal coefficients is the planting of bioenergy crops in the South. Although the majority of biomass supply is coming from the Corn Belt, some biomass from bioenergy crop is harvested in the Southern and Southeastern part of the United States. It is unknown at this time whether a limited number of cellulosic ethanol plants will emerge in those parts based on the limited supply of biomass (see figure 6). As long as there are is no cellulosic biofuel industry emerging in the South, no switchgrass or miscanthus will be planted. There are large coal-fired power plants in the Southern Part of the country (Dumortier, 2013a) and thus, there exists potential demand for bioenergy crops irrespective of a cellulosic transportation fuel industry. In addition, the Southeastern part of the United States is part of an increasing trend of exporting wood pellets from the U.S. to Europe (EIA, 2014). Any land use decisions in the Southeastern U.S. will be affected by these alternative uses but such an analysis is outside the scope of this paper.

Most studies assume the establishment costs are annualized over the lifetime of the bioenergy crop. In reality, landowners face a one-time switching cost and a one year lag period where no revenue occurs. This initial switching cost as well as the delayed return may hinder the landowners' investment in bioenergy crops (Song et al., 2011). This would result in a higher share of feedstock

\footnotetext{
${ }^{1}$ Illinois, Indiana, Iowa, Kansas, Minnesota, Nebraska, North Dakota, Ohio, South Dakota, and Wisconsin.
} 
coming from agricultural residues. As seen in table 4, the establishment cost in the first year for miscanthus is significant.

The current model does not explicitly take crop rotations at the county level into account. This would significantly increase the computational burden of the model because each landowner would have to decide on a potential crop rotation. We believe that incorporating crop rotation in our model would slightly increase the amount of biofuel derived from crop residues, especially corn stover. Especially in the presence of pasture availability for conversion to bioenergy crops, the number of hectares switching from a corn-soybean to a corn-corn-soybean rotation might not be substantial.

The effect of a majority of ethanol being produced from agricultural residues on the lifecycle emissions has not been analyzed in the present paper. Liska et al. (2014) suggest that the removal of corn residue increases $\mathrm{CO}_{2}$ and decreases soil organic carbon. In addition, the the removal of crop residue requires the additional use of fertilizer, especially nitrogen in the case of corn stover. The harvest of corn stover and the associated nutrient replacement could increase the amount of nitrous oxide from increased fertilizer application. On the other hand, Wu et al. (2012) use the SWAT model to predict fertilizer loading in the Upper Mississippi river basin from harvesting corn stover and find that there is the potential of reduced nitrogen and phosphorous loadings from improved management and efficient nitrogen use.

In conclusion, results show a majority of the mandates analyzed are mainly covered by agricultural residues even at a production level of 60 billion liters of cellulosic biofuel. Only in one scenario with low input requirements for miscanthus do we see a large share of bioenergy crops covering the mandate. In all other cases, the mandate is covered to at least $50 \%$ by agricultural residues. This also suggests that the initial cellulosic biofuel production will use agricultural residue as a feedstock with bioenergy crops coming into production at a later point. Bioenergy crop production will likely occur in the Southern Plains and the Southeast. No bioenergy crops are grown in the Corn Belt. Despite the majority of bioenergy crops being grown in the Plains and the Southeast, the highest supply of biomass is still concentrated in the Corn Belt coming from agricultural residues. This is also where we would expect a cellulosic biomass industry to emerge. The commodity price effects are moderate. Corn stover and wheat straw affect the crop production only to a small extent because the harvest of crop residues does not interfere with the crop production, i.e., limited diversion of cropland is observed.

\section{Acknowledgement}

I would like to thank Scott Gerlt, Latha Baskaran, Lawrence Eaton and Fernando E. Miguez for providing me with cost data yield data for switchgrass and miscanthus. Pamela A. Martin and Deanna Malatesta provided important comments to this manuscript.

\section{References}

Babcock, B. A., Marette, S., Tréguer, D., 2011. Opportunity for profitable investments in cellulosic biofuels. Energy Policy 39 (2), 714-719.

Baskaran, L., Jager, H. I., Schweizer, P. E., Srinivasan, R., 2010. Progess toward evaluating the 
sustainability of switchgrass as a bioenergy crop using the SWAT model. Transactions of the American Society of Agricultural and Biological Engineers 53 (5), 1547-1556.

Brechbill, S. C., Tyner, W. E., Ileleji, K. E., 2011. The economics of biomass collection and transportation and its supply to Indiana cellulosic and electric utility facilities. Bioenergy Research 4, $171-152$.

Carriquiry, M. A., Du, X., Timilsina, G. R., 2011. Second generation biofuels: Economics and policies. Energy Policy 39, 4222-4234.

Chen, X., 2010. A dynamic analysis of U.S. biofuels policy impact on land-use, greenhouse gases and social welfare. Ph.D. thesis, University of Illinois at Urbana-Champaign.

Christian, D., Riche, A., Yates, N., 2008. Growth, yield and mineral content of miscanthus $\times$ giganteus grown as a biofuel for 14 successive harvests. Industrial Crops and Products 28 (3), $320-327$.

Duffy, M. D., Nanhou, V. Y., April 2001. Costs of producing switchgrass for biomass in southern Iowa. Tech. Rep. PM 1866, Iowa State University - University Extension.

Duffy, M. D., Nanhou, V. Y., 2002. Trends in New Crops and New Uses. New Crops and New Uses: Strength in Diversity. American Society of Horticultural Science, Ch. Costs of producing switchgrass for biomass in Southern Iowa.

Dumortier, J., 2013a. Co-firing in coal power plants and its impact on biomass feedstock availability. Energy Policy 60, 396-405.

Dumortier, J., 2013b. The effects of uncertainty under a cap-and-trade policy on afforestation in the United States. Environmental Research Letters 8, 044020.

Dumortier, J., Hayes, D. J., Carriquiry, M., Dong, F., Du, X., Elobeid, A., Fabiosa, J. F., Tokgoz, S., 2011. Sensitivity of carbon emission estimates from indirect land-use change. Applied Economic Perspectives and Policy 33 (3), 428-448.

EIA, 2012. Biofuels issues and trends. October, U.S. Energy Infoamrtion Administration.

EIA, 2014. U.S. wood pellet exports double in 2013 in response to growing European demand, http://www.eia.gov/todayinenergy/detail.cfm?id=16391 accessed 11 November 2014.

EISA, 19 December 2007. Public Law 110140 Energy Independence and Security Act of 2007, Sec. 202. Renewable Fuel Standard (a)(1). Public law.

EPA, 2014. Clean power plan proposed rule, http://www2.epa.gov/ carbon-pollution-standards/clean-power-plan-proposed-rule accessed 11 November 2014 .

Epplin, F. M., 1996. Cost to produce and deliver switchgrass biomass to an ethanol-conversion facility in the southern plains of the United States. Biomass and Bioenergy 11 (6), 459-467.

FAPRI, July 2011. FAPRI-MU Stochastic U.S. Crop Model Documentation. FAPRI-MU Report 09-11, Food and Agricultural Policy Research Institute. 
FAPRI, March 2012. U.S. Baseline Briefing Book: Projections for agricultural and biofuel markets. FAPRI-MU Report 01-12, Food and Agricultural Policy Research Institute.

FAPRI, March 2013. U.S. Baseline Briefing Book: Projections for agricultural and biofuel markets. FAPRI-MU Report 01-13, Food and Agricultural Policy Research Institute.

Fargione, J., Hill, J., Tilman, D., Polasky, S., Hawthorne, P., 2008. Land clearing and the biofuel carbon debt. Science 319, 1235.

Heaton, E. A., Dohleman, F. G., Long, S. P., 2008. Meeting US biofuel goals with less land: the potential of Miscanthus. Global Change Biology 14, 2000-2014.

Hertel, T. W., Golub, A. A., Jones, A. D., O’Hare, M., Plevin, R. J., , Kammen, D. M., 2010. Effects of us maize ethanol on global land use and greenhouse gas emissions: Estimating marketmediated responses. BioScience 60 (3), 223-231.

Jager, H. I., Baskaran, L. M., Brandt, C. C., Davis, E. B., Gunderson, C. A., Wullschleger, S. D., 2010. Empirical geographic modeling of switchgrass yields in the united states. Global Change Biology Bioenergy 2 (5), 248-234.

Jain, A. K., Khanna, M., Erickson, M., Huang, H., 2010. An integrated biogeochemical and economic analysis of bioenergy crops in the midwestern united states. Global Change Biology Bioenergy $2(5), 217-234$.

Khanna, M., Chen, X., Huang, H., Önal, H., 2011a. Supply of cellulosic biofuel feedstocks and regional production pattern. American Journal of Agricultural Economics 93 (2), 473-480.

Khanna, M., Dhungana, B., Clifton-Brown, J., 2008. Costs of producing miscanthus and switchgrass for bioenergy in Illinois. Biomass and Bioenergy 32, 482-493.

Khanna, M., Önal, H., Dhungana, B., Wander, M., 2011b. Economics of herbaceous bioenergy crops for electricity generation: Implications for greenhouse gas mitigation. Biomass and Bioenergy 35, $1474-1484$.

Lewandowski, I., Scurlock, J. M., Lindvall, E., Christou, M., 2003. The development and current status of perennial rhizomatous grasses as energy crops in the US and Europe. Biomass and Bioenergy 25 (4), 335-361.

Liska, A. J., Yang, H., Milner, M., Goddard, S., Blanco-Canqui, H., Pelton, M. P., Fang, X. X., Zhu, H., Suyker, A. E., 2014. Biofuels from crop residue can reduce soil carbon and increase $\mathrm{CO}_{2}$ emissions. Nature Climate Change 4, 398-401.

Mabee, W. E., McFarlane, P. N., Saddler, J. N., 2011. Biomass availability for lignocellulosic ethanol production. Biomass and Bioenergy 35, 4519-4529.

Mallory, M. L., Hayes, D. J., Babcock, B. A., 2011. Crop-based biofuel production with acreage competition and uncertainty. Land Economics 87 (4).

Meyer, S., Thompson, W., 2012. How do biofuel use mandates cause uncertainty? united states envornmental protection agency cellulosic waiver options. Applied Economic Perspectives and Policy 34 (4), 570-586. 
Miguez, F. E., Maughan, M., Bollero, G. A., 2012. Modeling spatial and dynamic variation in growth, yield, and yield stability of the bioenergy crops Miscanthus x giganteus and Panicum virgatum accross the conterminous United States. Global Change Biology Bioenergy 4, 509-520.

MSU Extension, 2013. Whats the nutrient value of wheat straw?, http://msue.anr.msu.edu/ news/whats_the_nutrient_value_of_wheat_straw accessed 10 May 2014.

ORNL, 2011. Biomass energy data book edition 4. Tech. rep., Oak Ridge National Laboratory.

OSU Extension, 2012. Estimating nutrient removal of wheat straw, http://agcrops.osu. edu/corn/newsletters/2012/2012-18/estimating-nutrient-removal-of-wheat-straw accessed 10 May 2014.

Perlack, R. D., Stokes, B. J., 2011. U.S. Billion-Ton Update: Biomass Supply for a Bioenergy and Bioproducts Industry. ORNL/TM-2011/224. Oak Ridge National Laboratory, Oak Ridge, TN, U.S. Department of Energy.

Perrin, R., Vogel, K., Schmer, M., Mitchell, R., 2008. Farm-scale production cost of switchgrass for biomass. Bioenergy Research 1, 91-97.

Searchinger, T., Heimlich, R., Houghton, R. A., Dong, F., Elobeid, A., Fabiosa, J., Tokgoz, S., Hayes, D., Yu, T.-H., 2008. Use of u.s. croplands for biofuels increases greenhouse gases through emissions from land-use change. Science 319 (5867), 1238-1240.

Sesmero, J. P., Gramig, B. M., 2013. Farmers' supply response, price of corn residue, and its economic viability as an energy feedstock. Bioenergy Research 6, 797-807.

Song, F., Zhao, J., Swinton, S. M., 2011. Switching to perennial energy crops under uncertainty and costly reversibility. American Journal of Agricultural Economics 93 (3), 768-783.

Swinton, S. M., Babcock, B. A., James, L. K., Bandaru, V., 2011. Higher us crop prices trigger little area expansion s omarginal land for biofuel crops is limited. Energy Policy 39, 5254-5258.

Thompson, J. L., Tyner, W. E., 2014. Corn stover for bioenergy production: Cost estimates and farmer supply response. Biomass and Bioenergy 62, 166-173.

Thomson, A. M., Izarrualde, R. C., West, T. O., Parrish, D. J., Tyler, D. D., Williams, J. R., December 2009. Simulating potential switchgrass production in the United States. Tech. Rep. 19072, Pacific Northwest National Laboratory.

Turhollow, A., July 2000. Costs of producing biomass from riparian buffer strips. Tech. Rep. ORNL/TM-1999/146, Oak Ridge National Laboratory.

USDA, 2012.

USDA Economic Research Service, 2011. Commodity costs and returns.

URL http://www.ers.usda.gov/data-products/fertilizer-use-and-price.aspx

Walsh, M. E., de la Torre Ugarte, D. G., Shapouri, H., Slinsky, S. P., 2003. Bioenergy crop production in the united states: Potential quantities, land use changes, and economic impacts on the agricultural sector. Environmental and Resource Economics 24 (4), 313-333. 
Wu, M., Demissie, Y., Yan, E., 2012. Simulated impact of future biofuel production on water quality and water cycle dynamics in the Upper Mississippi river basin. Biomass and Bioenergy $41,44-56$. 